\title{
Heavy metals in playgrounds in Lublin (E Poland): sources, pollution levels and health risk
}

\author{
Wojciech Zgłobicki ${ }^{1} \cdot$ Małgorzata Telecka $^{1} \cdot$ Sebastian Skupiński ${ }^{1}$
}

Received: 25 February 2020 / Accepted: 19 May 2020 / Published online: 14 June 2020

(C) The Author(s) 2020

\begin{abstract}
In the paper, the pollution of playgrounds in Lublin with heavy metals was assessed. Since playgrounds are a place of activity of children - the most vulnerable group of city residents, identifying the degree of pollution and the related health hazards is particularly important. 50 playgrounds were investigated, and samples were collected from three types of places: soil in the playgrounds, soil beneath the swings and soil in the sandpits (a total of 91 samples); heavy metal levels were determined in the < 0.05-mm fraction. The mean heavy metal levels were $\mathrm{Cd}-4.7 \mathrm{mg} \mathrm{kg}^{-1}, \mathrm{Cr}-192.4 \mathrm{mg} \mathrm{kg}^{-1}, \mathrm{Cu}-16.3 \mathrm{mg} \mathrm{kg}{ }^{-1}, \mathrm{Hg}-0.027 \mathrm{mg}$ $\mathrm{kg}^{-1}, \mathrm{Ni}-12.7 \mathrm{mg} \mathrm{kg}^{-1}, \mathrm{~Pb}-41 \mathrm{mg} \mathrm{kg}^{-1}$, and $\mathrm{Zn}-79.8 \mathrm{mg} \mathrm{kg}^{-1}$, and they were in the following order when normalised to the geochemical background: $\mathrm{Cd}>\mathrm{Cr}>\mathrm{Zn}>\mathrm{Pb}>\mathrm{Hg}>\mathrm{Ni}>\mathrm{Cu}$. The highest mean levels occurred in the case of soil collected from beneath the swings $\left(\mathrm{Cd}, \mathrm{Cr}, \mathrm{Ni}\right.$ and $\mathrm{Zn}$ ) or soil in the playgrounds $(\mathrm{Cu}, \mathrm{Hg}$ and $\mathrm{Pb})$. Geochemical indices such as $I_{g e o}$ and $E F$ indicate the lack of pollution or low level of pollution with $\mathrm{Cu}, \mathrm{Cr}, \mathrm{Ni}, \mathrm{Zn}$ and $\mathrm{Pb}$. Moderate or considerable pollution with $\mathrm{Cd}$ and, sporadically, with $\mathrm{Hg}$ occurred in some playgrounds. A significant ecological risk was found for all samples due to the presence of $\mathrm{Cd}$ and, for about $20 \%$ of the samples, the concentration of $\mathrm{Hg}$. In all the cases analysed, the values of health hazard indices $(H I, C R)$ for children are very low and well below the hazard threshold for each element.
\end{abstract}

Keywords Health risk · Heavy metals · Urban environment

\section{Introduction}

The occurrence of increased heavy metal levels is one of the significant threats to the human environment and health in urban areas (Wong et al. 2006; Guney et al. 2010; Charlesworth et al. 2011; Xia et al. 2011). Their levels in the environment are determined by natural factors and anthropogenic supply, i.e. industrial emissions, motor vehicle traffic, fuel combustion (Kabata-Pendias and Pendias 1999; Pasieczna 2003). Metals discharged into the atmosphere gradually accumulate in the soil. Wherever the soil is not protected by vegetation, heavy metals can be re-suspended and can occur at low heights - in human living space. This creates the

Responsible editor: Philippe Garrigues

Wojciech Zgłobicki

wojciech.zglobicki@umcs.pl

1 Institute of Earth and Environmental Sciences, Maria Curie-Skłodowska University, Kraśnicka 2D, 20-718 Lublin, Poland risk of toxic elements entering human bodies, which can pose a threat to their health (Aelion et al. 2008; Zheng et al. 2010; Charlesworth et al. 2011; Gope et al. 2017). Playgrounds are a special kind of space in this respect because the intensive resuspension of heavy metals accumulated in the soil occurs as a result of children's activity (wearing away of the topsoil), while the children staying in the playground are particularly exposed to the negative effect of toxic metals. Children are active close to the land surface and absorb the soil dust and the metals it contains by inhaling it or directly by ingesting it through the alimentary tract (Elom et al. 2013). In both cases, the fine dust fraction poses the greatest threat (Yamamoto et al. 2006). Higher concentrations of lead in dust on playground equipment comparing to soils where reported in Beijing by Peng et al. (2019). Therefore, it is important for persons using playgrounds to maintain personal hygiene, i.e. wash their hands.

The problem of the pollution of playgrounds has been taken up by researchers in various countries and cities, but few studies have been devoted to this topic, while the obtained results concerning the intensity of the threats vary. For example, De 
Miguel et al. (2007) studied heavy metal levels in 20 playgrounds in Madrid and found that increased As levels can be a health hazard. High levels of toxic elements occurred in the soils of playgrounds located in the service and industrial zones in Hong Kong (Wong and Mak 1997). Elom et al. (2013) examined samples from 29 playgrounds in NE England for the presence of $\mathrm{As}$ and $\mathrm{Pb}$ and found that the concentrations of these elements could be a health hazard. Similar conclusions were reached by Kicińska et al. (2017) and Kicińska (2018) who analysed the pollution of sandpits with heavy metals in health resorts in southern Poland. Although they found a considerable level of pollution with these elements, in particular As and $\mathrm{Cr}$, it was not high enough to pose a threat to health. Identifying the sources of pollution in playgrounds is a different matter. Research indicates that pollution originates from different sources: traffic, local and regional atmospheric deposition, natural sources (Jin et al. 2019).

The study objective was to assess heavy metal levels in the soil of playgrounds and the health hazard to children staying there. The chosen metals - $\mathrm{Cd}, \mathrm{Cr}, \mathrm{Cu}, \mathrm{Hg}, \mathrm{Ni}, \mathrm{Pb}$ and $\mathrm{Zn}-$ are commonly regarded as indices of environmental pollution caused by human activity in urban environments (De Miguel et al. 1997; Kabata-Pendias and Pendias 1999; Charlesworth et al. 2011). Studies on heavy metal levels in playgrounds and the health aspects had not been conducted in eastern Poland thus far.

\section{Materials and methods}

Lublin is a medium-sized city located in the north-western part of the Lublin Upland, eastern Poland (51 $08^{\prime} 23.31^{\prime \prime}-$ $51^{\circ} 17^{\prime} 47.61^{\prime \prime} \mathrm{N}, 22^{\circ} 27^{\prime} 15.41^{\prime \prime}-22^{\circ} 40^{\prime} 24.75^{\prime \prime}$ E). It covers an area of about $150 \mathrm{~km}^{2}$ and is inhabited by 350 thousand people. Lublin is now an academic, administrative and service centre. Small industrial areas are located in the eastern part of the city, and the influence of industrial emissions is spatially restricted due to the predominance of westerly winds. At present, not very large food, pharmaceutical, mechanical, chemical and construction industry enterprises operate in Lublin. Studies indicate a relatively low level of pollution of soils in the city with trace metals (Pasieczna 2003; Plak et al. 2010). The studies were primarily focused on the influence of motor vehicle traffic on the geochemistry of soils: samples were collected in the vicinity of streets. A not very high and decreasing level of street dust pollution with heavy metals was also found (Zgłobicki et al. 2018, 2019).

The samples were collected within 50 playgrounds located in different parts of the city (Fig. 1). The locations were varied: inside housing estates sheltered by residential buildings; in close proximity to roads with a high intensity of traffic; industrial zones; recreational areas. The selected playgrounds differed in terms of facilities (swings, sandpits, ladders, tennis tables, chess tables etc.) as well as kind of surface (lawn, sand, synthetic flooring, hard surface) (Fig. 2).

The soil and sand samples were collected on days without precipitation from late spring until early autumn 2018 and 2019. The samples were obtained with a spade at various sites within the playgrounds. Material from three types of sites was analysed: (a) soil in playgrounds; (b) soil beneath swings; (c) soil in sandpits. Thus, heavy metal levels in the material that is most frequently re-suspended and with which children are in direct contact were analysed. Since all three types of sites did not occur in some playgrounds, the number of samples collected differed and, therefore, 44 soil samples from the playgrounds, 23 soil samples from beneath the swings and 24 soil samples from the sandpits were examined.

The samples were collected with a spade up to the depth of $5 \mathrm{~cm}$ at 5 to 7 points. In the case of soil sampling, exposed places without a vegetation cover were preferred. All portions of soil and sand from one type of site were joined together and packed into plastic bags. The sample weight after drying ranged from 1 to $2 \mathrm{~kg}$. After being transported to the laboratory, the samples were stored in a warm place for 2 to 5 days for initial drying. In the subsequent stage, the samples were placed in porcelain evaporators and, if necessary, larger pieces of plants were removed. The drying in a laboratory dryer lasted for at least $6 \mathrm{~h}$, at $105{ }^{\circ} \mathrm{C}$. Analyses of heavy metals were carried out using the Epsilon 5 device from Panalytical and the ED-XRF method as well as the calibration curve method. The content of the analysed metals was determined in the $<0.05-\mathrm{mm}$ fraction. Samples for elementary analyses were prepared in the form of pressed tablets. Metal content was measured three times in each sample, and the mean of the measured values was accepted as the final result. The accuracy of the method was verified using reference material NCS DC 73385. The measurement error varied from 3 to $5 \%$. The measurement results for 10 samples of soils collected in the immediate vicinity of the city and not subject to direct anthropogenic impact were used to determine the natural levels of metals in the environment (geochemical background).

Mercury was determined using the AMA-254 analyser. The measurements were carried out several times for each sample, and the final result was the mean of all the measured values. The weights for individual determinations $(0.1-0.5 \mathrm{~g})$ were selected so that the greatest sensitivity scope of the device was used.

Descriptive statistics (average, minimum, maximum, coefficient of variation) were used to assess the variation of heavy metal concentration in the soil and sandpits. In order to determine the degree of pollution, the following geochemical indices were calculated: (i) geoaccumulation index $\left(I_{g e o}\right)$, (ii) enrichment factor $(E F)$, (iii) index of ecological risk $\left(E r_{\mathrm{i}}\right)$, and 


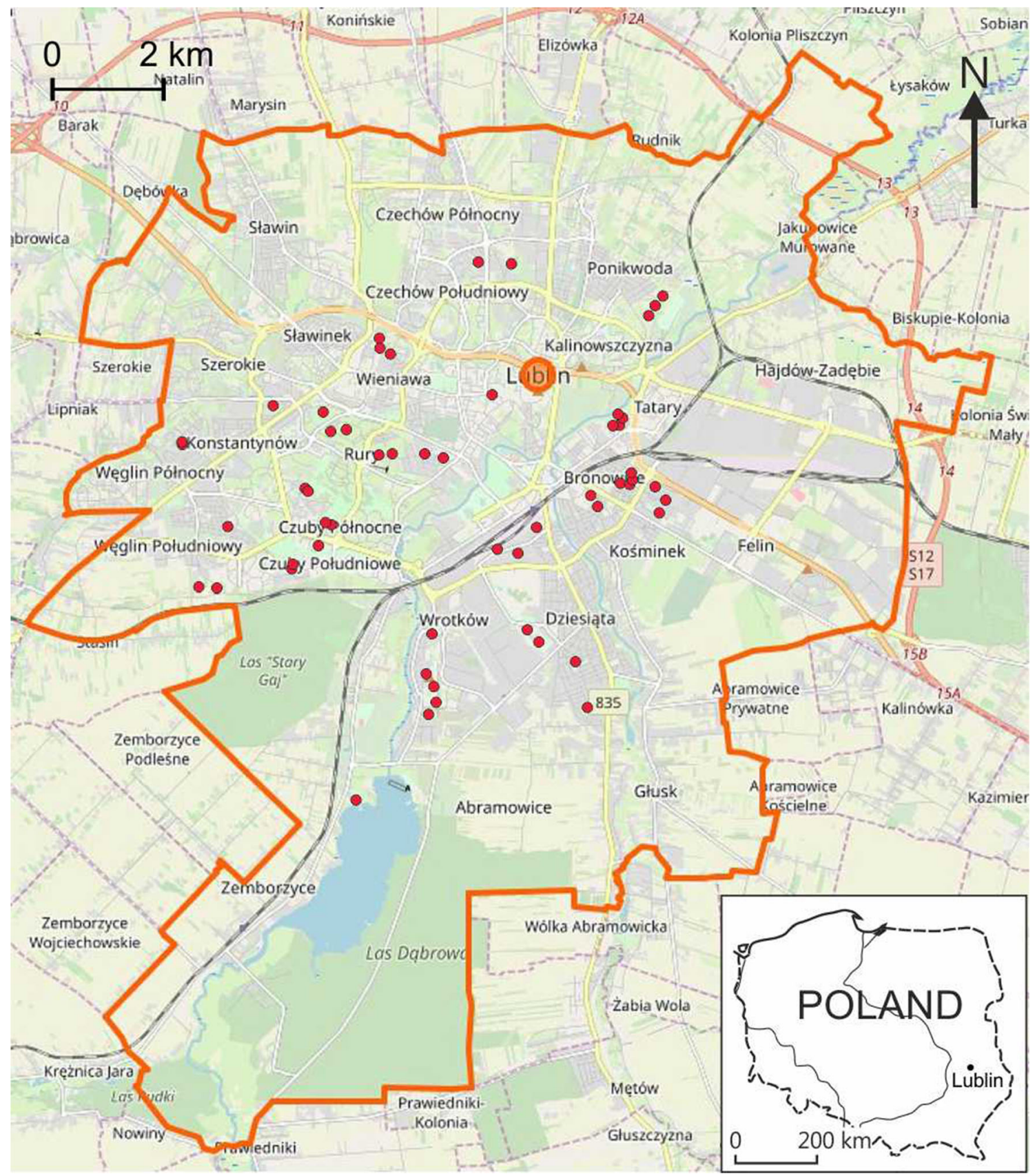

Fig. 1 Location of the playgrounds under study (background map source: Open Street Map)

Fig. 2 An example of sample collection points within a playground
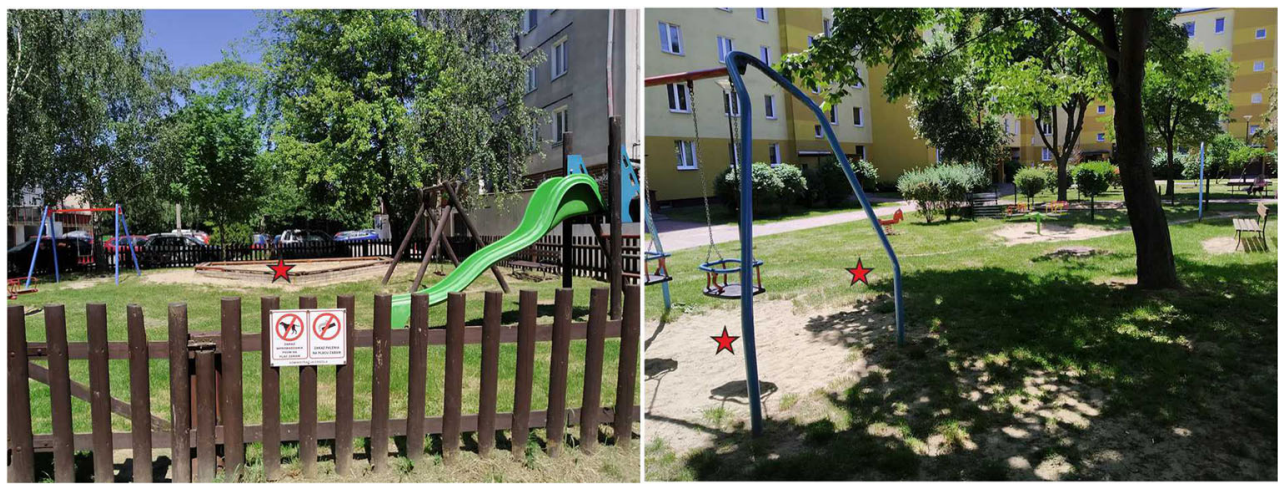
(iv) potential ecological risk index (RI) (Müller 1979; Håkanson 1980; Ergin et al. 1991; Zhao et al. 2015).

The geoaccumulation index is defined as follows:

$\mathrm{I}_{\text {geo }}=\log _{2}\left(\mathrm{C}_{\mathrm{n}} / 1.5 \mathrm{C}_{\text {ref }}\right)$

$C_{n}$ denotes the concentration of the metal, and $C_{r e f}$ value of the background. Six classes of pollution are distinguished according to Müller (1979): (1) unpolluted ( $\mathrm{I}_{\text {geo }}$ $<0$ ), (2) unpolluted to moderately polluted $(0-1)$, (3) moderately polluted (1-2), (4) moderately to strongly polluted (2-3), (5) highly polluted (3-4), (6) highly to extremely polluted (4-5), (7) extremely polluted (>5).

Enrichment factor is calculated with the following formula:

$E F=\frac{C_{n} / C_{r e f}}{B_{n} / B_{r e f}}$

$C_{n}$-metal concentration in a sample, $C_{r e f}$-background value for the metal, $B_{n}$-reference metal concentration in sample (in this study Mn was used as a reference element), $B_{r e f}$-background value for reference metal. Ergin et al. (1991) distinguish five of pollution: (1) minimal $(\mathrm{EF}<2)$, (2) moderate $(2-5)$, (3) significant (5-20), (4) very high (20-40), (5) extreme (> 40).

Index of ecological risk factor is defined by the following formula:

$E r_{i}=T_{i} \times \frac{C_{n}}{C_{r e f}}$

$\mathrm{T}_{\mathrm{i}}$ - toxic-response factor for the metal. Håkanson (1980) provides the following values for $\mathrm{T}_{\mathrm{i}}: \mathrm{Cd}-30, \mathrm{Cr}-2, \mathrm{Cu}-5$, $\mathrm{Ni}-5, \mathrm{~Pb}-5, \mathrm{Zn}-1$. Five categories of pollution are distinguished: (1) low (<40), (2) moderate (40-80), (3) considerable (80-160), (4) high (160-320), (5) very high (> 320).

Potential ecological risk $(R I)$ is defined as the sum of ecological risk factors indexes $\left(E r_{i}\right)$ for specific metals in a sample. Håkanson (1980) distinguished four categories of risk: (1) low (<150), (2) moderate (150-300), (3) considerable (300$600)$, (4) high (> 600).

The health hazard assessments combine the volume of environmental pollution with the probability of the toxic effect on people. The study uses the hazard index $(H I)$ and cancer risk $(C R)$ for a quantitative description of non-carcinogenic and carcinogenic risks related to the children's exposure to heavy metals within playgrounds (US EPA 2001, 2005). These models are commonly used in studies on the hazard posed, for example, by heavy metals in street dust or in the soil in playgrounds
(Jiang et al. 2017; Kicińska et al. 2017; Kicińska 2018; Pawełczyk et al. 2018; Safiur Rahman et al. 2019).

In the case of persons staying in a given area, there are three paths of direct contact with contaminants in soil and sand: (i) inhalation described with the parameter $D_{i n h}$, (ii) skin contact $\left(D_{\text {derm }}\right)$ and (iii) consumption $\left(D_{\text {ing }}\right)$. The exposure dose equations have the following form (US EPA 2005, 2011):

$$
\begin{aligned}
D_{\text {inh }} & =C \times \frac{i n h R \times E F \times E D}{P E F \times B W \times A T} \\
D_{\text {derm }} & =C \times \frac{S L \times S A \times A B S \times E F \times E D}{B W \times A T} \times 10^{-6} \\
D_{\text {ing }} & =C \times \frac{i n g R \times E F \times E D}{B W \times A T} \times 10^{-6}
\end{aligned}
$$

where $C$ - concentration of the element, ing $R$-ingestion rate dependent on the age, inh $R$-inhalation rate dependent on the age, $E F$-frequency of exposure to pollutants, $E D$ - exposure duration, $S A$-skin area exposed to pollutants, $S L$ - skin adherence factor, $A B S$ dermal absorption factor, $P E F$ - particle emission factor, $B W$-average body weight, $A T$-averaging time in days $(A T=E D \cdot 365)($ Table 1$)$.

The hazard index $(H I)$ is the sum total of hazards posed by the possible forms of pollutant absorption. It is calculated using the following equation:

$H I=\left(\frac{D i}{R f D}\right)_{i n g}+\left(\frac{D i}{R f D}\right)_{i n h}+\left(\frac{D i}{R f D}\right)_{\text {derm }}$

$D i$ is the dose of element $i$, and $R f D$ is the reference dose of the element. The proportions in the equation refer to noncarcinogenic effects. The probability of the occurrence of effects harmful to life is very low for $H I<1$, while the occurrence of negative effects is probable for $H I>1$ (US EPA 2005). In the case of $H I>4$, the hazard is regarded as high (Pawełczyk et al. 2018; Safiur Rahman et al. 2019). For carcinogenic metals (As, $\mathrm{Cd}, \mathrm{Cr}$, Ni etc.), the lifetime average daily dose $(L A D D)$ is expressed with the following equation:

$L A D D=C \times \frac{E F}{A T \times P E F} \times\left(\frac{C \text { Rchild } \times \text { EDchild }}{B \text { Wchild }}+\frac{C \text { Radult } \times \text { EDadult }}{B \text { Wadult }}\right)$

The equation takes into account the contaminants ingested by people or absorbed by inhaling polluted air, through skin contact with contaminated soil etc. in a specific time frame. For children, the equation takes the form:

$L A D D=C \times \frac{E F}{A T \times P E F} \times \frac{\text { CRchild } \times \text { EDchild }}{B W \text { child }}$ 
Table 1 Exposure parameters for the health risk assessment for children (6 years old)

\begin{tabular}{lll}
\hline Parameter & Value & Unit \\
\hline ingR (US EPA 2001) & 200 & $\mathrm{mg} \mathrm{day}^{-1}$ \\
inhR (Van den Berg 1995) & 7.6 & $\mathrm{~m}^{3}$ day $^{-1}$ \\
$E F$ (Safiur Rahman et al. 2019) & 230 & day year \\
$E D$ (US EPA 2001) & 6 & years \\
$S A$ (US EPA 2001) & 2800 & $\mathrm{~cm}^{2}$ \\
$S L$ (Safiur Rahman et al. 2019) & 0.2 & $\mathrm{mg} \mathrm{cm}^{-2}$ days $^{-1}$ \\
$A B S$ (US DOE, 2004) & 0.001 & - \\
$P E F$ (US EPA 2001) & $1,360,000,000$ & $\mathrm{~m}^{3} \mathrm{~kg}^{-1}$ \\
$B W$ (US EPA 1989) & 15 & $\mathrm{~kg}^{-1}$ \\
$A T 1$ (non-carcinogenic) (Kicińska 2018) & 2190 & days \\
$A T 2$ (carcinogenic) (Kicińska 2018, Safiur Rahman et al. 2019) & 25,550 & days \\
\hline
\end{tabular}

For carcinogenic substances, i.e. As, $\mathrm{Cd}, \mathrm{Cr}$, Ni etc., $L A D D$ values are multiplied by an appropriate slope factor $(S F)$ (Table 2), which enables the calculation of the cancer risk range (CR) (US EPA 2011)

$C R=S F \times L A D D$

Concentrations of metals can be regarded as hazardous to health when the cancer risk ranges $(C R)$ are greater than $10^{-6}$ or $10^{-4}$ (the lower risk level that would be universally accepted has not been determined yet) (US EPA 1989; Pawełczyk et al. 2018; Safiur Rahman et al. 2019).

The cancer risk range $C R$ is calculated for many substances as a sum of the risk for each of the metals studied:

$C R_{\text {tot }}=\sum_{i=1}^{n} C R_{i}$

where $C R_{i}$ is a partial risk calculated for element $i$, and $n$ is the number of elements analysed (Pawełczyk et al. 2018). In this case, the risk threshold is the same as for the cancer risk range calculated for a single element.

Principal Component Analysis (PCA) and Cluster Analysis (CA) were used to analyse the correlations between metal concentrations, which makes it possible to indicate the potential sources of their origin (Han et al. 2006; Tokalıoglu and Kartal 2006). The PCA method is used to generate substitute parameters that encompass groups of output parameters with a similar statistical variability. The Cluster Analysis (CA) method that was also used enables the geometrical grouping of data in clusters with similar coordinates (in this case the coordinates encompass concentrations of metals). In this study, the minimum variance method was used (Ward's method). Data normalised to the geochemical background were used in the cluster analysis. The normalisation of data enables the grouping of elements whose content levels are similar to the natural levels and elements whose levels exceed the geochemical background. The lack of normalisation to the local geochemical background can lead to mistaken conclusions when, for example, metals naturally occurring in high concentrations are grouped with metals whose concentrations are high as a result of human activity.

\section{Results}

The mean heavy metal levels, normalised to the geochemical background, were in the following order for the samples analysed: $\mathrm{Cd}>\mathrm{Cr}>\mathrm{Zn}>\mathrm{Pb}>\mathrm{Hg}>\mathrm{Ni}>\mathrm{Cu}$. $\mathrm{Cd}$ was the element with the highest degree of enrichment. Its mean

Table 2 The reference dose and slope factor of metals (carcinogenic elements are marked in italic)

\begin{tabular}{|c|c|c|c|c|c|c|c|}
\hline & $\mathrm{Cd}^{1}$ & $\mathrm{Cr}^{1}$ & $\mathrm{Cu}^{1}$ & $\mathrm{Hg}^{2}$ & $\mathrm{Ni}^{1}$ & $\mathrm{~Pb}^{1}$ & $\mathrm{Zn}^{1}$ \\
\hline$R f D_{\text {ing }}$ & 0.001 & 0.003 & 0.04 & 0.0003 & 0.02 & 0.0035 & 0.3 \\
\hline$R f D_{i n h}$ & 0.001 & 0.0286 & 0.042 & 0.0000857 & 0.0206 & 0.00352 & 0.3 \\
\hline$R f D_{\text {derm }}$ & 0.00001 & 0.00006 & 0.012 & 0.000021 & 0.0054 & 0.000525 & 0.06 \\
\hline$S F_{\text {ing }}$ & - & - & - & - & - & - & - \\
\hline$S F_{i n h}$ & 6.3 & 42 & - & - & 0.84 & - & - \\
\hline$S F_{\text {derm }}$ & - & - & - & - & - & - & - \\
\hline
\end{tabular}

${ }^{1}$ Safiur Rahman et al. 2019, ${ }^{2}$ Wang et al. 2019 
level in playgrounds was more than five times as high as in natural soil. The maximum level was nearly 10 times as high. Slightly lower enrichment rates were found for $\mathrm{Cr}$ : the mean was about 3 and the maximum was over 9 . The mean $\mathrm{Pb}$ and $\mathrm{Zn}$ levels were less than twice as high as the natural levels; the maximum levels were 9 and 11 times as high, respectively. $\mathrm{Cu}, \mathrm{Hg}$ and $\mathrm{Ni}$ concentrations were usually close to the levels in soil not affected by human impact. The maximum rates of enrichment of the individual $\mathrm{Cu}$ and $\mathrm{Ni}$ samples were 2.5-3.2. Hg was the element whose levels exceeded the natural levels the most in individual samples: the maximum level was 26 times as high, and the level in two samples was 15 times as high. A high variation of concentrations occurred for $\mathrm{Zn}, \mathrm{Pb}$ and $\mathrm{Cu}$, medium variation- for $\mathrm{Cr}$ and $\mathrm{Ni}$, and a low variation - for $\mathrm{Cd}$ (Table 3 ).

The average metal contents for $\mathrm{Cd}$ and $\mathrm{Cr}$ were slightly higher than the allowable concentrations for urban soils. For the remaining elements, in particular $\mathrm{Cu}$, $\mathrm{Hg}$ and $\mathrm{Ni}$, they were clearly lower than allowed (Table 3). They were exceeded by the maximum content in the case of $\mathrm{Cr}$ (3.7 times), $\mathrm{Cd}$ (2.2), $\mathrm{Pb}$ (1.9) and $\mathrm{Zn}$ (1.6).

The highest mean concentrations occurred in samples collected from beneath the swings $(\mathrm{Cd}, \mathrm{Cr}, \mathrm{Ni}$ and $\mathrm{Zn})$ and from the soil $(\mathrm{Cu}, \mathrm{Hg}$ and $\mathrm{Pb})$. The differences between the particular kinds of samples were not large, however (Table 4). Hg was the exception; its levels were twice as high in soil samples from the playgrounds as in samples from beneath the swings, and three times as high as in sandpits. The patterns were slightly different in the case of maximum values. The differences were clearly greater here (Table 5). The highest level of Hg in the soil was over seven times as high as the maximum level in the sandpits. The highest $\mathrm{Cr}$ level was found in one sandpit; it was similar in the case of $\mathrm{Ni}$. The highest levels of $\mathrm{Cu}, \mathrm{Hg}, \mathrm{Pb}$ and $\mathrm{Zn}$ occurred in the soil, and only in the case of $\mathrm{Cd}$ - beneath the swing.
Table 4 Mean heavy metal levels in various types of samples

\begin{tabular}{llllllll}
\hline Type of site & $\begin{array}{l}\mathrm{Cd} \\
\mathrm{mg} \mathrm{kg}^{-1}\end{array}$ & $\mathrm{Cu}$ & $\mathrm{Hg}$ & $\mathrm{Ni}$ & $\mathrm{Pb}$ & $\mathrm{Zn}$ \\
\hline Soil & 4.6 & 192.2 & 19.2 & 0.045 & 11.7 & 47.4 & 90.3 \\
Soil (under swing) & 5.1 & 209.3 & 17.5 & 0.022 & 13.8 & 40.2 & 97.5 \\
Sand box & 4.5 & 177.8 & 11.4 & 0.015 & 13.6 & 32.0 & 52.6 \\
\hline
\end{tabular}

\section{Geoaccumulation index}

There was no pollution with $\mathrm{Cu}, \mathrm{Ni}$ and $\mathrm{Zn}$, and no pollution with $\mathrm{Pb}$ and $\mathrm{Cr}$ for most of the samples. Medium pollution with $\mathrm{Pb}$ and $\mathrm{Cr}$ was found in a few samples (in the sandpits and beneath the swings). Pollution with Cd occurred in about $44 \%$ of the samples (soil in the playgrounds and beneath the swings). The pollution with $\mathrm{Hg}$ was at a medium level in two samples while high and very high pollution occurred in two and four soil samples, respectively (Table 6). Sample variation (variation coefficient) for $I_{\text {geo }}$ was low for $\mathrm{Cr}, \mathrm{Cd}$ and $\mathrm{Ni}$, slightly higher for $\mathrm{Cu}, \mathrm{Pb}$ and $\mathrm{Zn}$, while the geoaccumulation index for $\mathrm{Hg}$ showed the highest variation, from -2.4 to 4.2 (Table 6).

\section{Enrichment factor}

The minimum enrichment was found for $\mathrm{Cu}$ and $\mathrm{Ni}$, and for some $\mathrm{Zn}$ samples. A poor enrichment with Cr occurred for most samples; some samples also had a poor enrichment with $\mathrm{Pb}$ and $\mathrm{Zn}$. A considerable pollution with $\mathrm{Cd}$ was found in $53 \%$ of the samples (soil in the playgrounds and beneath the swings). A considerable enrichment with $\mathrm{Cr}, \mathrm{Pb}$ and $\mathrm{Zn}$ occurred in a few samples. In the case of one sample from a sandpit, a very strong enrichment with $\mathrm{Cd}$ was found. A strong pollution with $\mathrm{Hg}$ also occurred in nine samples, including two samples where it was very high.
Table 3 Content of heavy metals in playgrounds $(<50 \mu \mathrm{m}$ fraction) in Lublin $\left(\mathrm{mg} \mathrm{kg}^{-1}\right)$

\begin{tabular}{|c|c|c|c|c|c|c|c|}
\hline & $\mathrm{Cd}$ & $\mathrm{Cr}$ & $\mathrm{Cu}$ & $\mathrm{Hg}$ & $\mathrm{Ni}$ & $\mathrm{Pb}$ & $\mathrm{Zn}$ \\
\hline Mean value & 4.7 & 192.4 & 16.3 & 0.027 & 12.7 & 41.0 & 79.8 \\
\hline Median & 4.5 & 201.3 & 15.5 & 0.021 & 12.0 & 38.2 & 78.3 \\
\hline Min. value & 3.0 & 71.9 & 1.3 & 0.005 & 3.8 & 11.0 & 9.1 \\
\hline Max. value & 8.8 & 566.6 & 60.4 & 0.54 & 31.7 & 191.2 & 476.1 \\
\hline Standard deviation & 1.1 & 81.5 & 10.6 & 0.090 & 4.5 & 29.8 & 72.6 \\
\hline Variation coefficient (VC) $(\%)$ & 23 & 42 & 65 & 300 & 35 & 72 & 90 \\
\hline Standard error & 0.11 & 8.54 & 1.11 & 0.009 & 0.47 & 3.12 & 7.61 \\
\hline Mean value in street dust ${ }^{1}$ & 5.5 & 112.0 & 120.6 & $0.39^{2}$ & 17.1 & 46.6 & 296.2 \\
\hline Geochemical background & 0.8 & 60.0 & 17.8 & 0.019 & 12.4 & 21.4 & 41.3 \\
\hline Limit values for soils of urbanised areas ${ }^{3}$ & 4 & 150 & 150 & 2 & 100 & 100 & 300 \\
\hline
\end{tabular}

${ }^{1}$ Zgłobicki et al. 2019 (content in $<50-\mu \mathrm{m}$ fraction), ${ }^{2}$ unpublished data, ${ }^{3}$ Dz.U.02.165.1359 2002 
Table 5 Maximum heavy metal levels in various types of samples

\begin{tabular}{llllllll}
\hline Type of site & $\begin{array}{l}\mathrm{Cd} \\
\mathrm{mg} \mathrm{kg}^{-1}\end{array}$ & $\mathrm{Cu}$ & $\mathrm{Hg}$ & $\mathrm{Ni}$ & $\mathrm{Pb}$ & $\mathrm{Zn}$ \\
\hline Soil & 7.7 & 306.1 & 60.4 & 0.541 & 27.6 & 191.2 & 476.0 \\
Soil (under swing) & 8.8 & 448.1 & 56.0 & 0.272 & 27.5 & 168.2 & 421.0 \\
Sand box & 7.7 & 566.6 & 28.2 & 0.074 & 31.7 & 65.5 & 107.9 \\
\hline
\end{tabular}

\section{Ecological risk factor}

Low levels of pollution were found for all elements except $\mathrm{Cd}$. $35 \%$ of the samples showed a considerable pollution with $\mathrm{Cd}$ while a high level of pollution was found in $65 \%$ of the samples; a very high level of pollution occurred in one sample and a medium level in the remaining samples. A very high level of pollution with Hg occurred in eight samples, a high level - in three, and a considerable level—in 15 samples (Table 6).

\section{Potential ecological risk}

Most of the samples (66\%) had a moderate level of pollution (risk) and 33\% - a considerable and high level. This concerned all three kinds of samples and resulted from the presence of toxic elements such as $\mathrm{Cd}$ and $\mathrm{Hg}$. Cd showed a stable considerable and high level while Hg levels showed a considerable variation and fluctuated between a neutral and extreme level.

As was the case with absolute values, the soil in playgrounds had slightly higher geochemical indices than the sandpits (Table 7). For the enrichment factor, half of the soil samples from playground areas had a moderate level of pollution with metals such as $\mathrm{Cd}, \mathrm{Cr}, \mathrm{Hg}, \mathrm{Pb}$ and $\mathrm{Zn}$. The same level of this index for $\mathrm{Cd}$ and $\mathrm{Cr}$ occurred in soil samples from beneath the swings and from the sandpits. Half of the soil samples from beneath the swings had a high level of pollution with $\mathrm{Cd}$ in the case of the ecological risk index.

Playgrounds with the highest level of pollution occurred in the central part of the city, in the vicinity of the main streets and in the industrial and service district (Fig. 3).

\section{Statistical analysis}

PCA results indicate that the three principal components account for $80 \%$ of variability (Table 8 ). The influence of elements on the components is also the basis for distinguishing groups of metals with similar characteristics. These groups are distinguished on the variability of elements, not their content. Therefore, one group can contain metals whose levels are similar to the background levels as well as metals whose levels considerably exceed the background levels. A similar variability of the levels of these metals is of key importance as it can suggest a similar origin (e.g. anthropogenic, or from rocks containing a considerable amount of these metals). The first component is mostly influenced by $\mathrm{Cu}, \mathrm{Pb}, \mathrm{Zn}$ and $\mathrm{Ni}$, while the second one - by Cd, $\mathrm{Cr}$ and $\mathrm{Hg}$ (Fig. 4).

CA results show the existence of five separate statistical groups:
Table 6 Descriptive statistics of geochemical indices

\begin{tabular}{|c|c|c|c|c|c|c|c|}
\hline & $\mathrm{Cd}$ & $\mathrm{Cr}$ & $\mathrm{Cu}$ & $\mathrm{Hg}$ & $\mathrm{Ni}$ & $\mathrm{Pb}$ & $\mathrm{Zn}$ \\
\hline \multicolumn{8}{|l|}{ Geoaccumulation index } \\
\hline Mean & 1.97 & 1.09 & -0.70 & -0.08 & -0.54 & 0.35 & 0.36 \\
\hline Median & 1.90 & 1.16 & -0.78 & -0.45 & -0.62 & 0.25 & 0.33 \\
\hline Standard deviation & 0.30 & 0.54 & 0.78 & 1.43 & 0.42 & 0.61 & 0.84 \\
\hline Variation coefficient & 0.15 & 0.50 & -1.10 & -17.76 & -0.77 & 1.74 & 2.29 \\
\hline Share of polluted samples ${ }^{1}$ & $40.7 \%$ & $7.7 \%$ & $0 \%$ & $8.8 \%$ & $0 \%$ & $4.4 \%$ & $4.4 \%$ \\
\hline \multicolumn{8}{|l|}{ Enrichment factor } \\
\hline Mean & 5.39 & 2.96 & 0.91 & 2.51 & 0.88 & 1.83 & 1.99 \\
\hline Median & 5.10 & 3.04 & 0.83 & 1.08 & 0.89 & 1.64 & 1.73 \\
\hline Standard deviation & 3.19 & 1.33 & 0.57 & 4.35 & 0.19 & 1.09 & 1.52 \\
\hline Variation coefficient & 0.59 & 0.44 & 0.62 & 1.73 & 0.21 & 0.59 & 0.76 \\
\hline Share of polluted samples ${ }^{1}$ & $52.7 \%$ & $3.3 \%$ & $0 \%$ & $9.9 \%$ & $0 \%$ & $3.3 \%$ & $5.5 \%$ \\
\hline \multicolumn{8}{|l|}{ Ecological risk factor } \\
\hline Mean & 181.28 & 6.88 & 5.26 & 111.17 & 5.36 & 10.74 & 2.31 \\
\hline Median & 168.6 & 6.70 & 4.35 & 43.71 & 4.85 & 8.93 & 1.89 \\
\hline Standard deviation & 41.94 & 2.73 & 2.99 & 194.68 & 1.81 & 7.00 & 1.76 \\
\hline Variation coefficient & 0.23 & 0.39 & 0.56 & 1.75 & 0.33 & 0.65 & 0.76 \\
\hline Share of polluted samples ${ }^{1}$ & $91(100 \%)$ & $0(0 \%)$ & $0(0 \%)$ & $54(59.3 \%)$ & $0(0 \%)$ & $2(2.2 \%)$ & $0(0 \%)$ \\
\hline
\end{tabular}

${ }^{1}$ share of samples (\%), for which specific index is above the level "not polluted" 
Table 7 Geochemical indexes for different types of sites (median)

\begin{tabular}{|c|c|c|c|c|c|c|c|c|}
\hline & & $\mathrm{Cd}$ & $\mathrm{Cr}$ & $\mathrm{Cu}$ & $\mathrm{Hg}$ & $\mathrm{Ni}$ & $\mathrm{Pb}$ & $\mathrm{Zn}$ \\
\hline \multirow{3}{*}{ Geoaccumulation index } & Soil & 1.9 & 1.1 & -0.5 & 0.6 & -0.6 & 0.5 & 0.5 \\
\hline & Swing & 2.0 & 1.2 & -0.6 & -0.3 & -0.4 & 0.3 & 0.6 \\
\hline & Sandbox & 1.9 & 1.0 & -1.2 & -1.1 & -0.4 & 0.0 & -0.2 \\
\hline \multirow{3}{*}{ Enrichment factor } & Soil & 5.8 & 3.2 & 1.1 & 3.9 & 0.9 & 2.3 & 2.4 \\
\hline & Swing & 5.3 & 3.0 & 0.9 & 1.9 & 0.9 & 1.7 & 2.2 \\
\hline & Sandbox & 4.7 & 2.5 & 0.5 & 0.5 & 0.7 & 1.0 & 0.9 \\
\hline \multirow{3}{*}{ Ecological risk index } & Soil & 178.1 & 6.5 & 6.0 & 166.4 & 4.8 & 12.4 & 2.6 \\
\hline & Swing & 195.3 & 7.5 & 5.4 & 87.6 & 5.8 & 10.4 & 2.7 \\
\hline & Sandbox & 173.6 & 6.8 & 3.7 & 32.0 & 5.9 & 7.9 & 1.4 \\
\hline \multirow{3}{*}{ Ecological risk } & Soil & & & & 376.9 & & & \\
\hline & Swing & & & & 314.8 & & & \\
\hline & Sandbox & & & & 232.1 & & & \\
\hline
\end{tabular}

1. $\mathrm{Ni}, \mathrm{Cu}$ - within the background levels or slightly exceeding them

2. $\mathrm{Zn}, \mathrm{Pb}$ - two to three times as high as the background (more than twice as high on average)

3. $\mathrm{Cr}$ - four to five times as high as the background (more than 3.5 times on average)

4. $\mathrm{Cd}-$ over six times as high as the background and at the same time showing little variability with regard to content levels

5. $\mathrm{Hg}$ - on average twice as high as the background but having the greatest variability of content levels which can exceed the background the most - up to 27 times as high as the geochemical background

\section{Health risk}

The values of indices describing the risk of carcinogenic and non-carcinogenic effects on the health of 6-year-old children within the playgrounds under study are very low. In all the analysed cases, the value of the hazard index $(H I)$ is significantly below the hazard threshold for each element. Similarly in the case of cancer risk range index $(C R)$ whose value for each of the elements analysed was well below the lower risk threshold, i.e. $10^{-6}$. For all the elements under study, it was from 0 to $10^{-10}$. This value was slightly below $10^{-6}$ only for $\mathrm{Cr}$, but even then, it was still below the risk threshold (Table 9).

For 12 samples examined, mainly those from sandpits, the cancer risk range indices are below the $10^{-6}$ threshold. The other samples are below the less strict threshold at $10^{-4}$, and exceed the $10^{-6}$ threshold only slightly. This means that all the sites investigated are safe from the threat of non-carcinogenic and carcinogenic effects (Table 9).

The mean values of the hazard index are well below the health risk threshold and range from 0.0001 for $\mathrm{Hg}$ to 0.056 for $\mathrm{Cr}$. The standard deviation of $H I$ is small and shows that in all the cases analysed, the hazard index is below the hazard threshold, and there is no risk of non-carcinogenic health effects.

$C R$ for $\mathrm{Cu}, \mathrm{Hg}, \mathrm{Pb}$ and $\mathrm{Zn}$ is zero, with an accuracy of $10^{-15}$. The highest $C R$ occurs for chromium and its mean value is $5.3 \times 10^{-6} \pm 8.9 \times 10^{-6}$. The variability index is 1.69 , which means that $C R$ is highly variable for this element. $\mathrm{Ni}$ is also characterised by a high variability, but the $C R$ values for $\mathrm{Ni}$ are extremely low and do not exceed $3.6 \times 10^{-10}$.

For the total $C R$, the mean is $5.3 \times 10^{-6}$, the median is $3.1 \times$ $10^{-6}$, and standard deviation is $8.9 \times 10^{-6}$. The maximum value of $C R_{\text {tot }}$ for the analysed samples is $6.97 \times 10^{-5}$, which means that the sample with the highest degree of pollution with metals is still within the safety limit of $10^{-6}-10^{-4}$. The variability index for $C R_{\text {tot }}$ is 1.69 . Most playgrounds with the highest $C R_{\text {tot }}$ values are located in the eastern and south-eastern, i.e. the most industrialised, part of the city (Fig. 5).

\section{Discussion}

A direct comparison of the obtained study results with data presented by other authors is difficult due to the different methods used to determine concentrations and examine the levels of metals in different granulometric fractions. However, it can be concluded that clearly greater amounts of $\mathrm{Cd}$ and $\mathrm{Cr}$ occurred in Lublin than in other cities, $\mathrm{Cu}$ and $\mathrm{Ni}$ levels were similar to the levels provided by other authors, while $\mathrm{Pb}$ and $\mathrm{Zn}$ levels were slightly lower. Similarly to the results of earlier studies, the levels of heavy metals in the sandpits were clearly lower than in the soil of the playgrounds in Lublin (Table 10).

A direct comparison of the identified health hazard with the results of studies conducted in other cities is not easy either due to the use of different methodologies to assess the concentration of metals, the fraction in which the concentration was determined, and the indices adopted in the calculations 


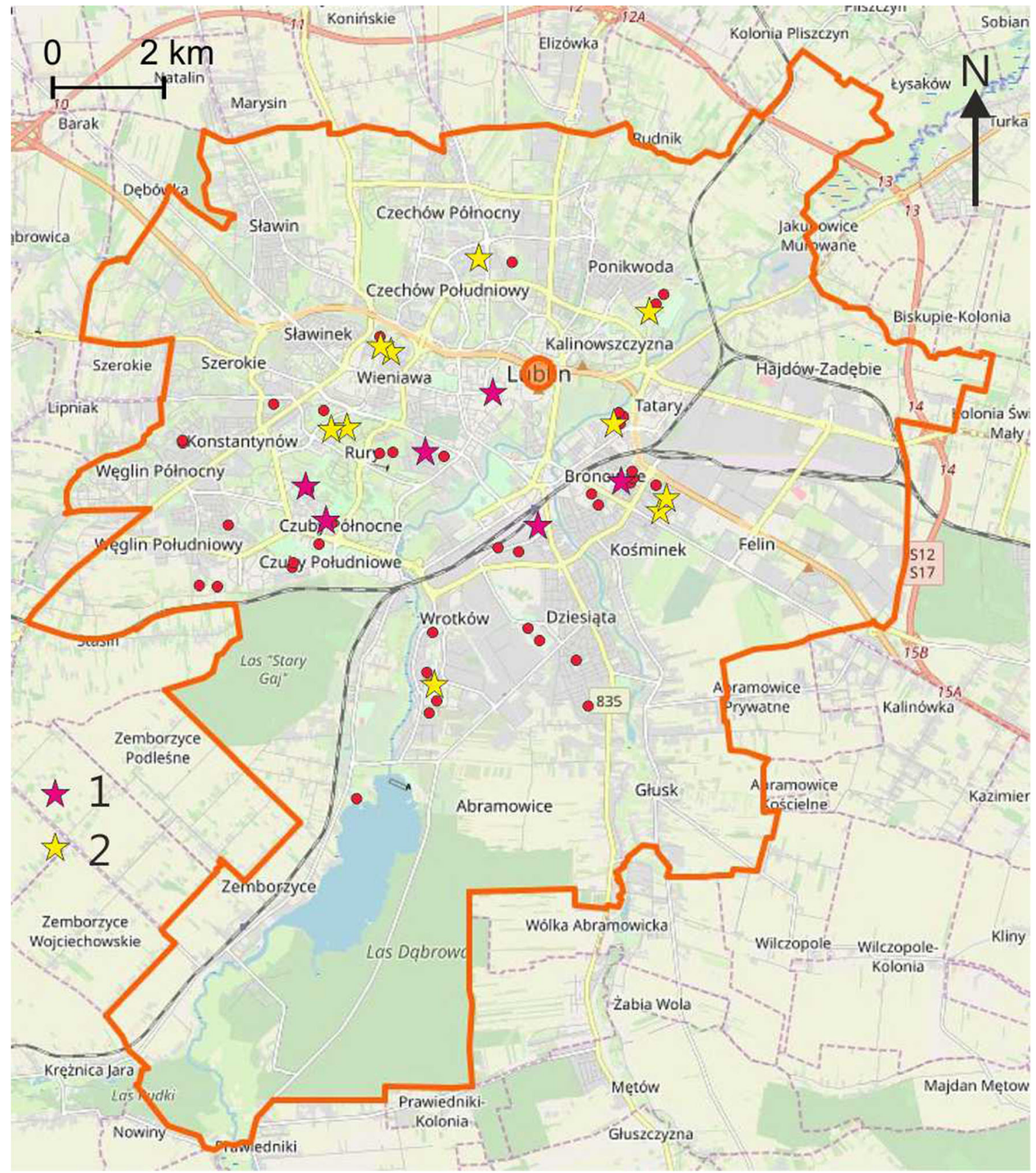

Fig. 3 The most polluted playgrounds (based on the relation to the geochemical background and geochemical indices) 1 - very high and high pollution, 2 - high and considerable pollution (background map source: Open Street Map)

Table 8 Fragment of the matrix of eigenvectors with four principal components (italics indicate statistically important impact)

\begin{tabular}{lllll}
\hline & Component I & Component II & Component III & Component IV \\
\hline $\mathrm{Cd}$ & -0.490 & -0.660 & 0.272 & -0.483 \\
$\mathrm{Cr}$ & -0.352 & -0.716 & -0.590 & 0.070 \\
$\mathrm{Cu}$ & -0.876 & 0.183 & -0.150 & -0.105 \\
$\mathrm{Hg}$ & -0.352 & -0.716 & -0.590 & 0.070 \\
$\mathrm{Ni}$ & -0.605 & -0.533 & 0.325 & 0.477 \\
$\mathrm{~Pb}$ & -0.912 & 0.230 & -0.011 & -0.011 \\
$\mathrm{Zn}$ & -0.866 & 0.159 & 0.106 & 0.025 \\
Variation percentage & 51.166 & 23.573 & 8.188 & 6.838 \\
Total variation $(\%)$ & 51.166 & 74.7 & 83 & 89.8 \\
\hline
\end{tabular}




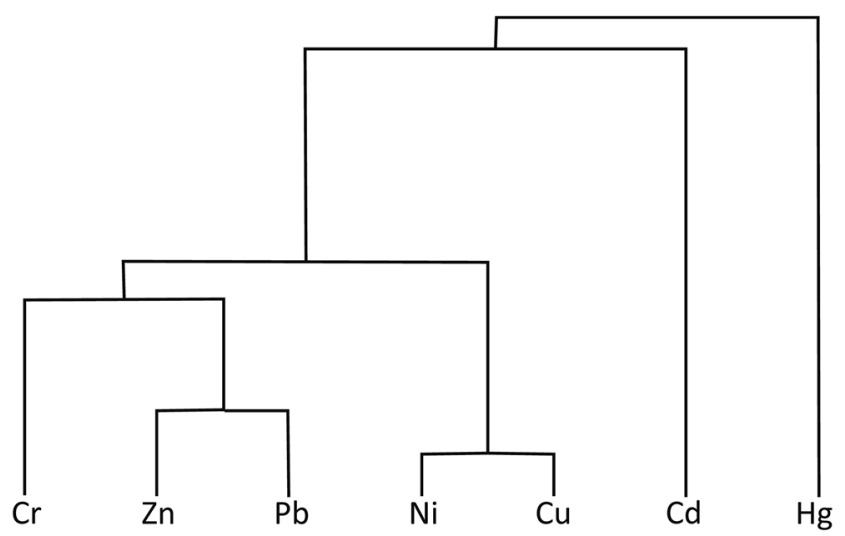

Fig. 4 Results of cluster analysis, using Ward's method, for data normalised to the background values

(exposure duration, body weight etc.). For Lublin, in all the analysed samples, the $H I$ value is well below the risk threshold for non-carcinogenic effects on health. As it was stated earlier (Table 3), soils of Lublin are not polluted and the health risk caused by heavy metals is low.

A comparison with the results for Madrid shows that the health hazard is lower in the case of copper, nickel, zinc and lead (Table 11). In the case of cadmium, the value of this index is higher, but still well below the lower hazard threshold. The $H I$ value for chromium is twice as high in Lublin than in Madrid and as much as four times as high as in the health resorts in southern Poland. The threats related to the presence of chromium in the soil of playgrounds were highlighted by Kicińska et al. (2017). The $H I$ for playgrounds in health resorts in southern Poland is higher for $\mathrm{Ni}, \mathrm{Zn}, \mathrm{Cd}$, comparable for $\mathrm{Cu}$, while the hazard index for $\mathrm{Cr}$ and $\mathrm{Pb}$ is higher in Lublin (Table 11).

Carcinogenic and non-carcinogenic elements can be absorbed by the organism through ingestion, inhalation and skin contact. In all the cases analysed in the study, the ingestion of contaminated material was the key factor influencing the possible health hazard. The same conclusions were reached by Kicińska (2018) who studied playgrounds in health resorts in southern Poland. In Lublin, the mean value of $D_{\text {ing }}$ is the highest for $\mathrm{Cr}\left(1.5 \times 10^{-3}\right)$ and the lowest for $\mathrm{Hg}$ $\left(3.96 \times 10^{-8}\right)$. The highest mean value of $D_{i n h}$ was $4.2 \times 10^{-9}$ for $\mathrm{Cr}$ and $1.1 \times 10^{-12}$ for $\mathrm{Hg}$, while that of $D_{\text {derm }}$ was $4.1 \times$ $10^{-7}$ for $\mathrm{Cr}$ and $1.1 \times 10^{-10}$ for $\mathrm{Hg}$. The other mean values of indices were between the mean values for $\mathrm{Cr}$ and mean values for $\mathrm{Hg}$ (Table 12). In the analysed situation, the ingestion of contaminated soil or sand from a sandpit occurs through the swallowing of the polluted material itself, not while eating food, as is most often the case with agricultural soil. It should be concluded, therefore, that the absorption of pollutants by children is even lower for the areas under study than what can be inferred from the theoretical calculations. The ingestion of polluted soil is rather accidental and sporadic although the amount of the material absorbed on a single occasion can be significant in some cases. Therefore, it should be concluded that the ingestion of contaminated soil by persons staying in playgrounds is not hazardous to health, in terms of the occurrence of carcinogenic and non-carcinogenic effects. At the same time, the pollution of soil with heavy metals does not always translate to a direct health hazard identified according to the accepted methodology of risk assessment because the harmfulness of the metals under study varies. In some cases, even if the concentration of a metal is considerably higher than the geochemical background, it does not lead to significant potential health effects. However, this problem undoubtedly requires further research on the influence of a long-lasting supply of small doses of heavy metals to the human body.

Elements whose levels are higher than the geochemical background, such as $\mathrm{Cd}, \mathrm{Hg}, \mathrm{Cr}, \mathrm{Zn}$ and $\mathrm{Pb}$, are of anthropogenic origin and the intensity of their supply varies, while $\mathrm{Ni}$ and $\mathrm{Cu}$ are mostly of natural origin. $\mathrm{Pb}$ and $\mathrm{Zn}$ are characterised by similar levels in relation to the background as well as similar variability, which suggests they are of mixed
Table 9 Variability of $H I$ and $C R$ indices within the playgrounds under study

\begin{tabular}{lrrrrrrrr}
\hline & \multicolumn{1}{c}{$\mathrm{Cd}$} & $\mathrm{Cr}$ & $\mathrm{Cu}$ & $\mathrm{Hg}$ & $\mathrm{Ni}$ & $\mathrm{Pb}$ & $\mathrm{Zn}$ \\
\hline & \multicolumn{1}{c}{$\mathrm{HI}$} & & & & & & & \\
Mean & 0.0045 & 0.056 & 0.0003 & 0.0001 & 0.0005 & 0.0096 & 0.0002 \\
Median & 0.0041 & 0.055 & 0.0003 & 0.00005 & 0.0004 & 0.0080 & 0.0002 \\
Max. value & 0.008 & 0.15 & 0.001 & 0.001 & 0.001 & 0.04 & 0.0012 \\
Standard deviation & 0.0010 & 0.022 & 0.0002 & 0.0002 & 0.0002 & 0.0063 & 0.0002 \\
Coefficient of variation & 0.2314 & 0.396 & 0.5697 & 1.7511 & 0.3381 & 0.6524 & 0.7629 \\
& $C R$ & & & & & & \\
Mean & $2 \times 10^{-9}$ & $5.3 \times 10^{-6}$ & 0 & 0 & $4 \times 10^{-11}$ & 0 & 0 \\
Median & $1.3 \times 10^{-9}$ & $3.1 \times 10^{-6}$ & 0 & 0 & $2 \times 10^{-11}$ & 0 & 0 \\
Max. value & $9.8 \times 10^{-9}$ & $6.9 \times 10^{-6}$ & 0 & 0 & $3.6 \times 10^{-10}$ & 0 & 0 \\
Standard deviation & $1.5 \times 10^{-9}$ & $8.9 \times 10^{-6}$ & 0 & 0 & $5 \times 10^{-11}$ & 0 & 0 \\
Coefficient of variation & 0.811 & 1.69 & 0 & 0 & 1.27 & 0 & 0 \\
\hline
\end{tabular}




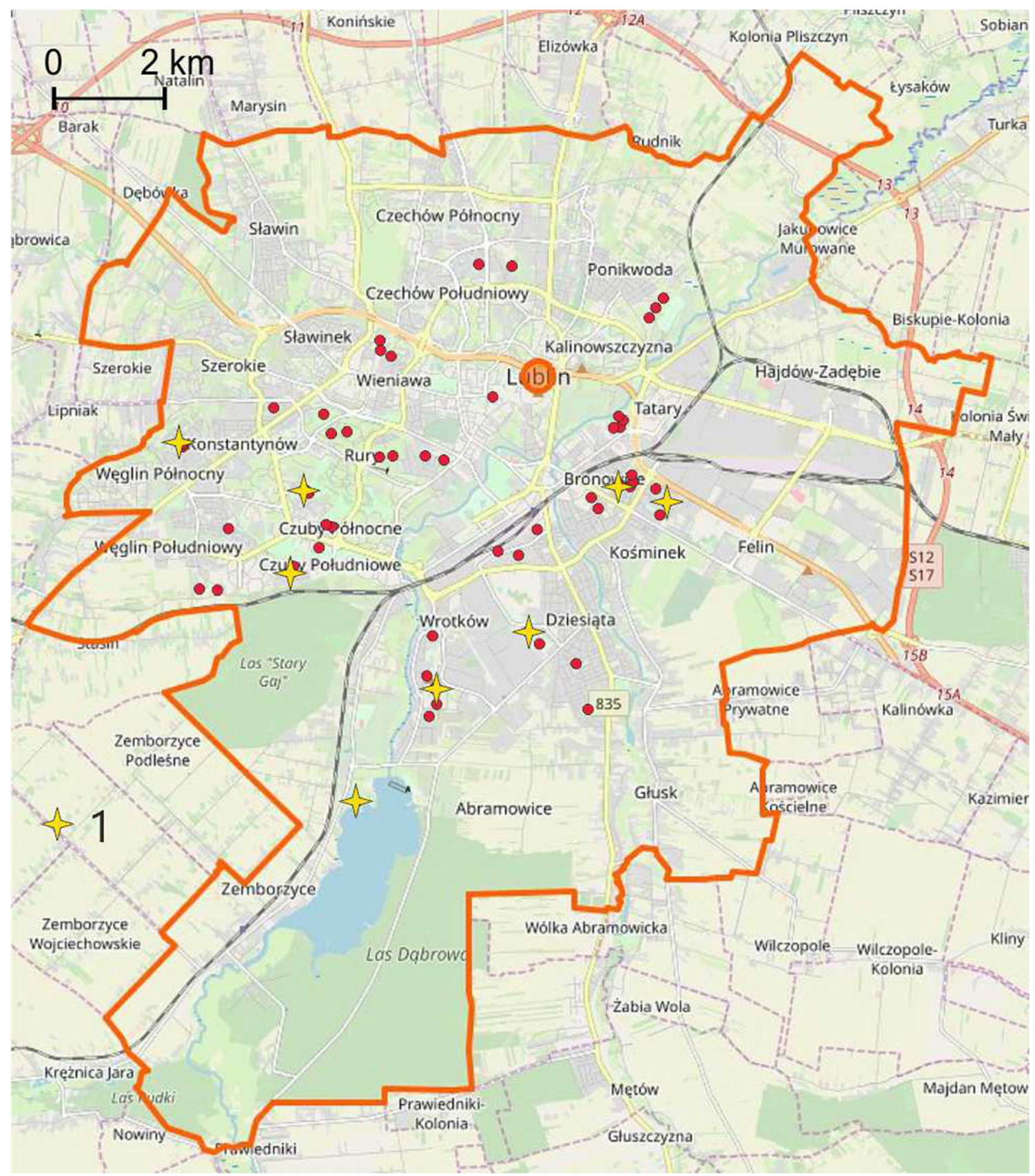

Fig. 5 Playgrounds with the highest $\mathrm{CR}_{\text {tot }}$ index (1) (background map source: Open Street Map)

origin - anthropogenic and natural. $\mathrm{Cd}$ and $\mathrm{Cr}$ also exceed the geochemical background by a similar margin and have a similar variability, and can thus be regarded as elements of anthropogenic origin. $\mathrm{Hg}$ is a special element whose levels in most samples are similar to the natural levels but, in the case of a few playgrounds, exceed the background by a very high margin as a result of anthropogenic supply. In Poland, the main source of $\mathrm{Hg}$ emissions into the atmosphere is fuel combustion $(63 \%)$, production of construction materials $(26 \%)$, metallurgy (5\%), chemical industry (4\%) and waste combustion (2\%) (Hławiczka and Fudała 2003). In Lublin, the location of sites most highly polluted with $\mathrm{Hg}$ to the highest degree indicates pollution caused by $\mathrm{Hg}$ emissions into the atmosphere as a result of fuel combustion in private homes.

Thus, the anthropogenic pollution of the soil in playgrounds seems to be a result of atmospheric deposition. The burning of fuels (coal, wood and other fuels) in private homes is the main source of metals discharged into the atmosphere in Lublin. In the eastern and south-eastern part of the city, the impact of industry and services can also be a contributing factor. The mean concentrations of the metals under study in playgrounds, normalised to the background values, are in the following order: $\mathrm{Cd}>\mathrm{Cr}>\mathrm{Pb}(\mathrm{Zn})>\mathrm{Hg}>\mathrm{Ni}>\mathrm{Cu}$. The order is slightly different than in the case of street dust $(\mathrm{Zn}>\mathrm{Cd}>$ 


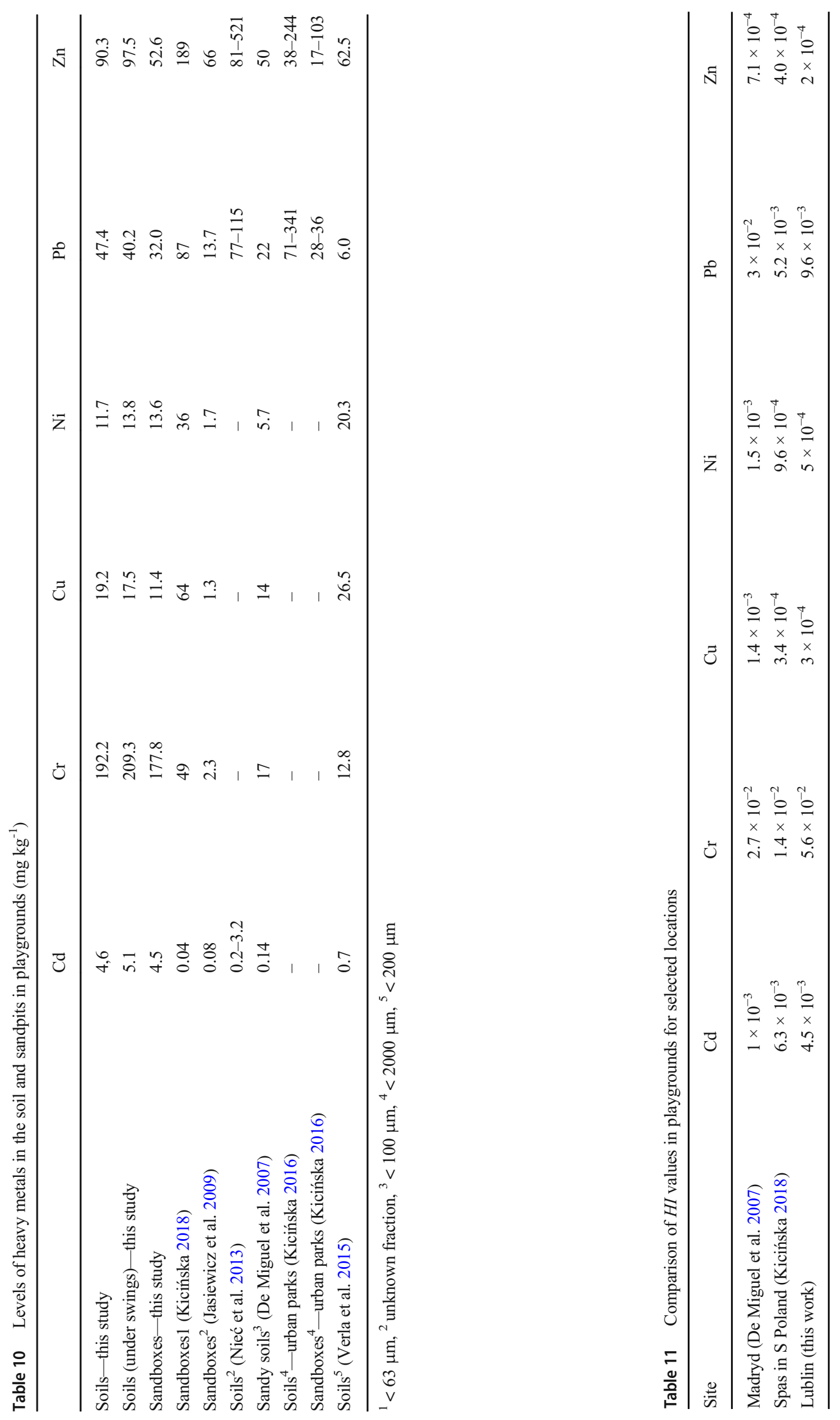


Table 12 Maximum and mean values of components of the hazard index: $D_{\text {ing }} D_{\text {inh }}$ and $D_{\text {derm }}$

\begin{tabular}{|c|c|c|c|c|c|c|c|}
\hline & $\mathrm{Cd}$ & $\mathrm{Cr}$ & $\mathrm{Cu}$ & $\mathrm{Hg}$ & $\mathrm{Ni}$ & $\mathrm{Pb}$ & $\mathrm{Zn}$ \\
\hline Mean value $D_{\text {ing }}$ & $3.5 \times 10^{-6}$ & $1.5 \times 10^{-3}$ & $1.35 \times 10^{-5}$ & $3.96 \times 10^{-8}$ & $9.6 \times 10^{-6}$ & $3.3 \times 10^{-5}$ & $6.9 \times 10^{-5}$ \\
\hline Max. value $D_{\text {ing }}$ & $6.3 \times 10^{-6}$ & $4 \times 10^{-3}$ & $4.3 \times 10^{-5}$ & $3.9 \times 10^{-7}$ & $2.2 \times 10^{-5}$ & $1.3 \times 10^{-4}$ & $3 \times 10^{-4}$ \\
\hline Mean value $D_{i n h}$ & $9.7 \times 10^{-11}$ & $4.2 \times 10^{-9}$ & $3.8 \times 10^{-10}$ & $1.1 \times 10^{-12}$ & $2.7 \times 10^{-10}$ & $9.3 \times 10^{-10}$ & $1.9 \times 10^{-9}$ \\
\hline Max. value $D_{i n h}$ & $1.8 \times 10^{-10}$ & $1.1 \times 10^{-8}$ & $1.2 \times 10^{-9}$ & $1.1 \times 10^{-11}$ & $6.4 \times 10^{-10}$ & $3.8 \times 10^{-9}$ & $9.6 \times 10^{-9}$ \\
\hline Mean value $D_{\text {derm }}$ & $9.7 \times 10^{-9}$ & $4.1 \times 10^{-7}$ & $3.7 \times 10^{-8}$ & $1.1 \times 10^{-10}$ & $2.6 \times 10^{-8}$ & $9.3 \times 10^{-8}$ & $1.9 \times 10^{-7}$ \\
\hline Max. value $D_{\text {derm }}$ & $1.77 \times 10^{-8}$ & $1.1 \times 10^{-6}$ & $1.2 \times 10^{-7}$ & $1.09 \times 10^{-9}$ & $6.4 \times 10^{-8}$ & $3.86 \times 10^{-7}$ & $9.6 \times 10^{-7}$ \\
\hline
\end{tabular}

$\mathrm{Cu}>\mathrm{Cr}>\mathrm{Pb}>\mathrm{Ni}$ ), which may indicate that, in general, street dust is not a significant source of pollution of the soil in playgrounds (Zgłobicki et al. 2018). Locally, however, it can cause increased levels of heavy metals in the air and soil, particularly in the case of elements such as $\mathrm{Cu}$ and $\mathrm{Zn}$. High concentrations in the soil in playgrounds were found in a few cases in the vicinity of streets with a high intensity of traffic (Fig. 4). The spatial distribution of the playgrounds with the highest concentrations of metals does not indicate any significant patterns and clear correlation with the city's functional zones. This may indicate a significant role of local factors influencing atmospheric circulation such as topographic location, housing development patterns etc. Plak (2018) arrived at similar conclusions and noted that, in the case of the residential zones of Lublin, Torun and Kraków, it is difficult to indicate one source of pollution with heavy metals.

\section{Conclusions}

The studied metals supplied to the soil in the playgrounds were of varying origin. $\mathrm{Cu}$ and $\mathrm{Ni}$ can be regarded as elements of natural origin, $\mathrm{Pb}$ and $\mathrm{Zn}$ - of mixed origin, and $\mathrm{Cd}, \mathrm{Cr}$ and $\mathrm{Hg}-$ of anthropogenic origin. In the case of the latter, some playgrounds showed a very intensive influence of human activity, while in other playgrounds, this influence was distinctly smaller.

$\mathrm{Cd}$ was the element with the highest degree of enrichment in relation to the natural levels (5 times) while a slightly smaller degree of enrichment was found for $\mathrm{Cr}$ (3 times). The geochemical background was exceeded most (26 times) in a single sample in the case of $\mathrm{Hg}$. The values of geochemical indices show that the environment of playgrounds is polluted with $\mathrm{Cd}$, in a few cases also with $\mathrm{Hg}$ and $\mathrm{Cr}$. The highest mean concentrations occurred in samples collected from beneath the swings $(\mathrm{Cd}, \mathrm{Cr}$, $\mathrm{Ni}$ and $\mathrm{Zn})$ or from the soil $(\mathrm{Cu}, \mathrm{Hg}$ and $\mathrm{Pb})$. The differences between the particular kinds of samples were not large; however, they were the largest for $\mathrm{Hg}$ and the smallest for $\mathrm{Cu}$ and $\mathrm{Zn}$.

The values of indices describing the risk of carcinogenic and non-carcinogenic effects on health within the playgrounds under study are very low. $\mathrm{Cr}$ is the element posing the greatest threat. Also in this case, however, the health hazard indices are below the permitted limits. The ingestion of material containing metals was the key factor influencing the possibility of health effects, while inhalation and direct skin contact were clearly less significant (the volume of supply was smaller by several orders of magnitude).

The spatial distribution of playgrounds with the highest degree of pollution with heavy metals and the highest health hazard does not show a clear pattern. Factors conducive to higher concentrations include location within industrial and service districts, old parts of the city where stoves are used for heating as well as the proximity of streets with a high intensity of traffic.

Open Access This article is licensed under a Creative Commons Attribution 4.0 International License, which permits use, sharing, adaptation, distribution and reproduction in any medium or format, as long as you give appropriate credit to the original author(s) and the source, provide a link to the Creative Commons licence, and indicate if changes were made. The images or other third party material in this article are included in the article's Creative Commons licence, unless indicated otherwise in a credit line to the material. If material is not included in the article's Creative Commons licence and your intended use is not permitted by statutory regulation or exceeds the permitted use, you will need to obtain permission directly from the copyright holder. To view a copy of this licence, visit http://creativecommons.org/licenses/by/4.0/.

\section{References}

Aelion CM, Davis HT, McDermott S, Lawson AB (2008) Metal concentrations in rural topsoil in South Carolina: potential for human health impact. Sci Total Environ 402:149-156

Charlesworth S, De Miguel E, Ordonez A (2011) A review of the distribution of particulate trace elements in urban terrestrial environments and its application to consideration of risk. Environ Geochem Health 33(2):103-123

De Miguel E, Llamas JF, Chacón E, Berg T, Larssen S, Røyset O, Vadset M (1997) Origin and patterns of distribution of trace elements in street dust: Unleaded petrol and urban lead. Atmos Environ 31 (17): 2733-2740

De Miguel E, Iribarren I, Chacon E, Ordonez A, Charlesworth S (2007) Risk-based evaluation of the exposure of children to trace elements in playgrounds in Madrid (Spain). Chemosphere 66:505-513

Dz.U.02.165.1359 - Rozporządzenie Ministra Środowiska z dnia 9 września 2002 r. w sprawie standardów jakości gleby oraz standardów jakości ziemi 
Elom NI, Entwistle JA, Dean JR (2013) How safe is the playground? An environmental health risk assessment of As and $\mathrm{Pb}$ levels in school playing fields in NE England. Environ Chem Lett 11:343-351

Ergin M, Saydam C, Basturk O, Erdem E, Yoruk R (1991) Metal concentrations in surface sediments from the two coastal inlets (Golden Horn Estuary and Izmit Bay) of the northeastern Sea of Marmara. Chem Geol 91:269-285

Gope M, Masto RE, George J, Hoque RR, Balachandran S (2017) Bioavailability and health risk of some potentially toxic elements $(\mathrm{Cd}, \mathrm{Cu}, \mathrm{Pb}$ and $\mathrm{Zn})$ in street dust of Asansol, India. Ecotox Environ Safe 138:231-241

Guney M, Zagury GJ, Dogan N, Onay TT (2010) Exposure assessment and risk characterization from trace elements following soil ingestion by children exposed to playgrounds, parks, and picnic. J Hazard Mat 182(103):656-664

Håkanson L (1980) An ecological risk index for aquatic pollution control: a sedimentological approach. Water Res 14:975-1001

Han YM, Du PX, Cao JJ, Posmentier ES (2006) Multivariate analysis of heavy metal pollution in urban dusts of Xi'an, Central China. Sci Total Environ 355:176-186

Hławiczka S, Fudała J (2003) Główne kategorie źródeł emisji metali ciężkich do powietrza w Polsce. II. Emisja rtęci, Ochrona Powietrza i Problemy Odpadów 37(5):135-142

Jasiewicz CZ, Baran A, Antonkiewicz J (2009) Assessment of chemical composition and sanitary state of sand in selected sandboxes in Krakow. J. Elementol. 14(1):79-90

Jiang Y, Chao S, Liu J, Yang Y, Chen Y, Zhang A, Cao H (2017) Source apportionment and health risk assessment of heavy metals in soil for a township in Jiangsu Province, China. Chemosphere 168:16581668

Jin Y, O'Connor D, Ok YS, Tsang DCW, Liu A, Hou D (2019) Assessment of sources of heavy metals in soil and dust at children's playgrounds in Beijing using GIS and multivariate statistical analysis. Environment International 124:320-328

Kabata-Pendias A, Pendias H (1999) Biogeochemistry of trace elements. PWN:279-288

Kicińska A (2016) Health risk to children exposed to $\mathrm{Zn}, \mathrm{Pb}$ and $\mathrm{Fe}$ in selected urban parks of the Silesian agglomeration. Hum Ecol Risk Assess Int J 22(8):1687-1695

Kicińska A (2018) Health risk assessment related to an effect of sample size fractions: methodological remarks. Stochastic Environmental Research and Risk Assessment 32:1867-1887

Kicińska A, Mamak M, Skrzypek M (2017) Heavy metals in sands of sandboxes: health risk associated with their quantities and form of occurrence in some spas of Poland. Environ Sci Pollut Res 24: 19733-19748

Müller G (1979) Schwermetalle in den Sedimenten des RheinsVeränderungen seit 1971. Umschau 24:778-783

Nieć J, Baranowska R, Dziubanek G, Rogala D (2013) Children's exposure to heavy metals in the soils of playgrounds, sports fields, sandpits and kindergarten grounds in the region of Upper Silesia. J Ecol Health 17(2):55-62

Pasieczna A (2003) Atlas zanieczyszczeń gleb miejskich w Polsce. Państw. Inst. Geol. Warszawa, pp 1-83

Pawełczyk A, Božek F, Zuber M (2018) Environmental risk. Case studies. Czech-Pol Trade, Prague

Peng T, O'Connor D, Zhao B, Jin Y, Zhang Y, Tian L, Zheng N, Li X, Hou D (2019) Spatial distribution of lead contamination in soil and equipment dust at children's playgrounds in Beijing, China. Environmental Pollution 245:363-370

Plak A (2018) Funkcje miasta a zawartość i rozmieszczenie metali ciężkich, metaloidów i pierwiastków ziem rzadkich w glebach miejskich. Wydawnictwo YMCS, Lublin
Plak A, Bartmiński P, Dębicki R (2010) Wpływ transportu publicznego na zawartość wybranych metali ciężkich w glebach sąsiadujących z ulicami Lublina. Proceedings of Ecopole 4(1):167-171

Safiur Rahman M, Khan MDH, Jolly YN, Kabir J, Akter S, Salam A (2019) Assessing risk to human health for heavy metal contamination through street dust in the Southeast Asian Megacity: Dhaka, Bangladesh. Sci Total Environ 660:1610-1622

Tokalığlu Ș, Kartal Ș (2006) Multivariate analysis of the data and speciation of heavy metals in street dust samples from the organized industrial district in Kayseri (Turkey). Atmos. Environ. 40:27972805

US EPA (1989) Risk assessment guidance for Superfund. Vol. I: human health evaluation manual (Part A), Interim Final. 1989. US Environmental Protection Agency, Office of Emergency and Remedial Response

US EPA (2001) US Environmental Protection Agency. Supplemental Guidance for Developing Soil Screening Levels for Superfund Sites. OSWER 9355.4-24. Office of Solid Waste and Emergency Response

US EPA (2005) Integrated Risk Information System (IRIS). http://www. epa.gov/iris

US EPA (2011) Exposure Factors Handbook, final ed. US Environmental Protection Agency, Washington, DC [EPA/600/R-09/052F]

Van den Berg R (1995) Human exposure to soil contamination: a qualitative and quantitative analysis towards proposals for human taxicological intervention values. RIVM Report No. 725201011. National Institute of Public Health and Environmental Protection (RIVM), Bilthoven, The Netherlands

Verla EN, Ibutume SA, Horsfall M (2015) A preliminary survey of heavy metals concentrations in children playground within Owerri metropolis, Imo state, Nigeria. Res J Chem Sci 5(11):1-8

Wang N, Jichang H, Yang W, Gang L, Yingying S (2019) Potential ecological risk and health risk assessment of heavy metals and metalloid in soil around Xunyang mining areas. Sustainability. 11:4828

Wong JWC, Mak NK (1997) Heavy metal pollution in children playgrounds in Hong Kong and its health implications. Environ. Technol. 18:109-115

Wong CSC, Li X, Thornton I (2006) Urban environmental geochemistry of trace metals. Environ. Pollut. 142:1-16

Xia X, Chen X, Liu R, Liu H (2011) Heavy metals in urban soils with various types of land use in Beijing, China. J Hazard Mater 186: 2043-2050

Yamamoto N, Takahashi Y, Yoshinaga J, Tanaka A, Shibata Y (2006) Size distributions of soil particles adhered to children's hands. Arch Environ Contam Toxicol 50:157-163

Zgłobicki W, Telecka M, Skupiński S, Pasierbińska A, Kozieł M (2018) Assessment of heavy metals contamination levels of the street dust in the city of Lublin. Environmental Earth Sciences 77:774

Zgłobicki W, Telecka M, Skupiński S (2019) Assessment of short-term changes in street dust pollution with heavy metals in Lublin (E Poland)-levels, sources and risks. Environmental Science and Pollution Research. 26:35049-35060

Zhao N, Lu X, Chao S (2015) Multivariate statistical analysis of heavy metals in less than $100 \mu \mathrm{m}$ particles of street dust from Xining, China. Environ Earth Sci 73:2319-2327

Zheng N, Liu J, Wang Q, Liang Z (2010) Health risk assessment of heavy metal exposure to street dust in the zinc smelting district, northeast of China. Sci Total Environ 408:726-733

Publisher's note Springer Nature remains neutral with regard to jurisdictional claims in published maps and institutional affiliations. 